Original article in the International Journal of Supply Chain and Operations Resilience. https://www.inderscience.com/info/inarticletoc.php?jcode $=$ ijscor\&year $=2018 \& v o l=3 \&$ issue $=2$

Cite this article as: Doussoulin, J.P. and Bittencourt, M. (2018) 'Analysing the circular economy opportunities in the French construction sector related to the sustainable supply chain: a waste input-output analysis', Int. J. Supply Chain and Operations Resilience, Vol. 3, No. 2, pp.143-162.

\title{
Analysing the circular economy opportunities in the French construction sector related to the sustainable supply chain: a waste input-output analysis
}

\author{
Jean Pierre Doussoulin and Mariana Bittencourt \\ Research Center for Management (LAREQUOI) \\ University of Paris-Saclay, 47 Bld Vauban 78047 Guyancourt, France \\ Email: jean-pierre.doussoulin@upem.fr mariana.bittencourt@uvsq.fr
}

\begin{abstract}
The construction sector has long recognised the decisive role of the various phases of the building lifecycle in the global environment. The identification of the construction environmental impacts is a significant progress for the development of a sustainable supply chain related to the raw material consumption and the construction and demolition waste (C\&DW) generation. In this sense, circular economics' principles have solid potential to address these challenges in all European Union countries and especially in France. Nowadays, inputoutput (I/O) modelling covers the analysis of waste generation (WIO). As the supply chain of the building construction process is complex and has several related activities, and in a preliminary moment a conceptual model was developed, this approach provided an assessment of the mitigation actions of C\&DW generation in France. This evaluation shows some positive waste reduction of several materials in the construction process, especially in concrete, metal, rock/rubble and sand/soil. However, the same study exhibits that even materials that can be recycled in the construction process, e.g., concrete, plastic, and metal, might not have a positive waste reduction during demolition due to the lack of proper waste separation and contamination during the process.
\end{abstract}

Keywords: circular economy; construction sector; input-output analysis; waste; recycling; reuse; supply chain; sustainability. 


\section{Introduction}

The growth in the worldwide population has been stimulating the urbanisation phenomenon. Cities need building's structure to develop their economic activities but also to provide housing, education, health and other services for the population. Hence, they provide water, energy and raw materials to the building's construction and use. As an output, buildings are responsible for GHG emissions, waste production, and other environmental impacts.

A recent projection shows that the global population is expected to reach between 8.3 and 10.9 billion by 2050 (UN, 2012). This projection increases the social concerns to develop basic infrastructure for the global population and management of main global environmental issues from industrial sectors.

The construction industry has a decisive role in the reduction of global environmental problems, as for instance the ozone depletion, water and soil pollution, deforestation and global warming, along with the different stages of the building lifecycle (Rodríguez et al., 2011). These impacts are the result of the high consumption of natural resources and high waste generation (Gangolells et al., 2009), produced especially during the demolition phase (Jiménez et al., 2012).

Some of this waste can be recycled and reused, but still, in many cases, the landfill is still a common destination. An explanation for this can be found first of all in the waste composition. Waste is usually the mixtures of inert and organic materials. Public filling areas (road construction for instance) and construction sites often use the inert waste. However, the remaining waste is often mixed and contaminated, not suitable for reuse or recycling and is disposed of in the landfills (Shen et al., 2004).

There are some barriers in the application of circular economy in the construction sites. A considerable proportion of these boundaries is related to the economic costs of respecting the current legal framework and the need for additional time devoted to sorting out waste. Furthermore, the lack of space in construction sites to locate the different types of waste containers and the difficulty on tracking activities of subcontractors can be highlighted (Gangolells et al., 2014; Saez et al., 2013). 
On the other hand, a study of Gangolells et al. (2014) presented the factors that motivate construction companies to implement effective waste prevention and management actions in Spain. The authors found that current legislation, company's public image improvement, costs reduction, increase the company's competitiveness, and health and safety work conditions are the main factors that stimulate construction companies to be more responsible.

The implementation of sustainability concerns in the construction sector is about achieving a win-win outcome for all the stakeholders. A green building project requires sustainable performance in all the phases of the building lifecycle, and not just in the operation phase. For the US EPA (2016), green buildings “... is the practice of creating structures and using processes that are environmentally responsible and resource-efficient throughout a building's life-cycle from siting to design, construction, operation, maintenance, renovation, and deconstruction."

Hence, constructions sites need an efficient, sustainable management system to study the risks of biodiversity damages, water pollution, and soil contamination, to ensure that not just the building will be sustainable but also the whole construction process.

The sustainable management system should preview an effective waste management system to decrease the construction and demolition disposal. Common waste management practices can be determined in the design, in the planning, and the construction phase. As for instance, design project optimisation, use of prefabricated technologies, workers training programs, waste separation in different containers, site cleanness and order (Gangolells et al., 2014; Jaillon et al., 2009).

All these changes in the construction sector are part of a global change call towards a sustainable development of the economy. Governments and societies perceive this as an opportunity to deal with the serious challenge of global warming. Global warming represents big consequences as harmful adverse effects (Stern et al., 2006; OECD, 2008) and environmental pollution issues. 
France is the country of the European Union (EU) with the highest C\&DW generation rate. In 2010, the French C\&DW generation was about 260.2 million tons, almost $31 \%$ of total C\&DW generation in the EU - about 860 million tons (Eurostat, 2014) as is presented in Appendix A. Furthermore, the recycling rate in France in 2010 was $50 \%$ (SOeS, 2013).

The development of mitigation actions in the French construction sector related to the high material consumption and C\&DW generation should be a priority and attend the requirements of the EU Waste Framework Directive 2008/98/CE (European Parliament, 2008). Furthermore, the French National Program for Waste Prevention that establish, respectively, that waste valorisation must be increased at least $70 \%$ by weight in Europe by 2020, and that France must implement a circular economy model through a C\&DW management, prioritising recycle and reuse systems and reducing land filling.

Environmental advantages of C\&DW recycling are proven by Ortiz et al. (2010), evidencing the importance of avoiding land filling. Even if the environmental impacts of recycling strategies can exceed the environmental benefits, Blengini (2009) affirmed that, for the C\&DW, recycling process is 'economically feasible and profitable from the energetic and environmental point of view'.

Waste landfill induces substantial environmental impacts such as water and soil pollution, and greenhouse gases production (e.g., CO2 and methane) due to the waste anaerobic degradation ( $\mathrm{Lu}$ and Tam, 2013). Furthermore, it is the worst option for final waste destination because the embodied energy of the materials is not used (Vefago and Avellaneda, 2013).

Within this context, this paper aims to explore the different hypothetical scenarios to show the opportunities of the circular economy for the French construction sector. Promoting a closed-loop supply chain that could assist France to limit their greenhouse gas emissions. 
There have been very few studies about applying the Input-Output analysis in the construction sector. Acquaye and Duffy (2010) proposed a use an I/O analysis to determine the energy and GHG emissions for the Irish construction sector and subsector and Nässén et al. (2007) assessed the Swedish building using the top-down I/O analysis. In general, there is a lack of studies that propose an alternative of measuring of a closed loop. The added value of this paper is the application of closed-loop indicators to measure the recycling opportunities in the building sector in France.

\section{Method}

\subsection{Thermodynamic background}

The connection between thermodynamics and economics is a complex issue in ecological economics. Questions such as the entropy law or the conservation laws of mass and energy are relevant to economic consensus. The Thermodynamics Laws are pertinent to the economy because urban metabolism is 'entropic' or disordered in a system. The highly organised system is low-entropy (e.g., building), on the contrary, a system in disorder is supposed to be high-entropy (e.g., construction waste).

There have been several attempts to incorporate ecological issues into post-Keynesian models, to conciliate these visions. The method implicitly incorporates the laws of thermodynamics to draw on the flow-fund models of Georgescu-Roegen (1971, 1979, 1984). In 1971, Georgescu-Rogen made an important distinction between the flow resources according to the energy and matter (e.g., metal, wood, plastic, paper) and the fund resources (e.g., construction lift, workers). The energy and matter are the significant inflows in the building construction process. The fund resources refer to the support structure provided during the construction process. The resources are not transformed during the building process (Mayumi, 2001; Daly and Farley, 2011). 


\subsection{Circular flow context}

Passet's (1979) approach expresses the concept of insert the economic loop in the larger loop of the biosphere. It is appropriate to take a holistic approach to answer this question. It includes some issues such as climate change, resource depletion, desertification, the gap between wealth and poverty - all signals of climate change.

It is challenging to insist on clinging to the myth under the classical economics about the resource abundance (Bourg et al., 2010). It is equally ambitious to believe that the invisible hand of Adam Smith can get out of this ecological crisis. It is urgent to change the economic model, to find a mechanism to control the materials and energy flow growth. The circular economy concept responds to this question trying to change the mainstream pathway such as linear production towards an approach that used a circular material and energy flow in a global anthropogenic system. It is logic to question the circular economy ability (McDonough and Braungart, 2008) to propose a shift of paradigm.

In this sense, the transition from a 'linear flow' to a 'circular flow' requires a certain change of the economic model. In fact, the economy has recently witnessed a paradigm shift in the energy and resources price. During the twentieth century, the prices have steadily declined, and it is expected that this trend will be reversed in the next century. It means that supply could become a major problem and a source of political tensions. The physical stocks owners (e.g., private sector) will guarantee the supply conditions that are currently considered as property resources of tomorrow. The business model that makes this possible is based on the 'self-service' where economic actors retain ownership of their products and resources, contributing to the future supply and resources availability. In fact, two alternatives can be used to approach the problem: by characterising the production and technology in ecological perspectives (O'Connor, 1989); or by the contradiction between the cowboy economy, such as the resource depletion economy working with limited and non-renewable, and close material and energy flux such as a spaceship. 
The second factor to be considered is that biochemical loops have beginning and ending. It must be improved; manage their inventory, maintaining their value, quality and performance of the ecosystem services. The difference between an open and a closed loop is one of the most crucial differences between the circular and the linear approach or mainstream.

The third important factor is the speed of the circular flow. A model that works with distinct materials operated very slowly. In fact, on the other side of the spectrum, the recycling materials have a variable life cycle, such as aluminium cans. In this case, there is a fast flow and slow materials loss.

Regarding the circular pattern, it is important to distinguish between the extraction and the production processes. In fact, threequarters of the energy use to manufacture a product are focused on raw material extraction. Furthermore, the object manufacturing requires only $25 \%$ of the total energy. However, the environment is perceived as non- scarce, bringing a new discussion about the distribution justice and climate change.

Inevitably, climate change and scarcity are unavoidable. The circular economy should contribute reducing CO2 emissions and other greenhouse gases, reuse and surrender on the repackaged market product, minimize water extraction and waste generation, and strategies to retain materials.

To provide a critical analysis of the recycling level of construction, we applied a circular economy framework using the extended version of input-output table proposed by Li (2012).

\subsection{Circular economy of French construction sector: an input- output analysis approach}

The work proceeds, in one hand, by the development of mitigation actions in the French construction industry for reducing the material consumption and the C\&DW generation. On the contrary, for the analysis and comparison between the business-as-usual scenario (BAU) and the recycle scenario using the waste input-output (WIO) method. 
The review builds on scientifical knowledge in circular economy recognised frameworks to develop a holistic understanding of how the production and consumption process are conceived, despite much of this information published throughout the academic literature in government agency reports (Eurostat, 2014) as an input-output database.

In this sense, the multisector economic models are the most suitable instruments of applied economics to the national accounts analysis.

A whole group of multisector models with specific features is often associated with authors as Leontief, Von Neumann, and Sraffa. The common element its models can be summarised noting that all models have a standard orientation, in the sense that the issues analysed are close to the works of authors such as the Physiocrats, Ricardo, and Marx.

Following the tradition of Georgescu-Rogent $(1971,1979,1984)$ and the literature on physical input-output tables (Leontief, 1936; Isard et al., 1968; Daly, 1968; Victor, 1972). It is possible to classify the I/O models using different types of units such as monetary or physical units, such as tons of waste. Also, it is possible to classify the type of matrix assessing the interdependencies among economic sectors. Usually, the table is presented as a square matrix. Physical models are the reference for several models. The physical flow (energy, matter, and waste) are captured via physical input-output matrices.

These input-output models include:

- Leontief model: This model develops an extension of the traditional I/O considering the pollution including in one hand, extra rows to show the pollution generated by some sectors, and on the contrary including the pollution abatement costs that the waste proprietors must pay for cleaning the pollution.

- Victor model: Victor (1972) proposed a model that considered a sector-commodity (rows) by commodities-sector (columns) matrix to describe the economic transaction.

- Isard model: This author used Victor's model which does not consider the ecological process. Isard et al. (1968) addressed the issue of measuring the ecological process. It can be used to quantify the biochemical cycles such as carbon, phosphorus, water. 
- Daly model: This structure has four quadrants considering the interaction flows within the economy, flows from the environment to the economy, flows from the economy to the environment and flows in the biochemical cycles. Daly (1968) had a fundamental difference from Isard's model, adopting a configuration as a sector by sector or process by process, rather the commodities by sectors used by Isard.

Indeed, it possible to distinguish the physical flows according to their origin (source) and destination (sink). A typical presentation of these flows showed in the physical input- output table (PIOT) is a commodity by industry format in physical units, i.e., tons, Mtep. It is possible to present the PIOT using two asymmetric tables of inputs and outputs. In fact, there are two ways to express the symmetrical input-output table. First, it can be provided an inter-industrial material flow (industries by industries flow). Secondly, it can also be expressed by the materials, giving the quantitative relation between the material use (material by material flow) (Pedersen et al., 2006). These flows ensure that the First Law of Thermodynamics is satisfied. According to this law, matter or energy cannot be created or destroyed. These flows also considered the Second Law of Thermodynamics which implies that construction building process has a tendency to increase the entropy in the system (i.e., geosphere).

The PIOT not only shows the physical flow of commodities, but it also allows to include the waste generation. An example was the method to waste issues in the work of Duchin (1990). Also, Li (2012) suggested an indirect approach of the classical input- output method proposed by Leontief which examines the change in material flow through the circular economy issue.

In this sense, a key to understanding the concept of circular economy is through the study of their material supply. In this sense, we have an available data source on material consumption, which integrates economic and physical accounts of the national accounting, including accounts in France which allow us to explore the raw material evolution of construction sector. 
Therefore, and regarding the current political scenario, circular economy's principles have strong potential to address these challenges related to the construction sector, especially when transforming the raw material production and consumption, and in particular, in the French scenario.

Figure 1 represents the strategy of C\&DW management for the French construction sector scenario, implemented by the government to attend the $70 \%$ of reduction proposed by the EU Waste Framework Directive. The C\&DW is valorised through the recovery or recycling process, or incinerated (with or without energy recovery), or sent to a storage centre (IPHEN, 2007).

Figure 1 C\&DW management for the French construction sector

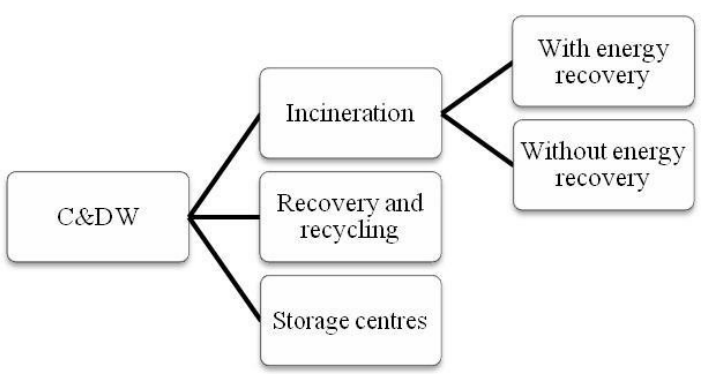

Source: IPHEN (2007)

The Waste Directive $\mathrm{n}^{\circ} 2008 / 98 / \mathrm{CE}$ (European Parliament, 2008) states the waste prevention act in five main points: prevention, reuse, recycling, valorisation, and disposal.

In the C\&DW management, firstly, it is assessed the possibility to do the waste separation inside the construction site. If that is not possible, a place for this purpose should be established. Different bins contribute to evaluating the destination in the waste separation process. These bins could be identified by colour or through a signpost to prevent mixing the various waste types. Depending on the waste it is possible to reuse or recycle. When there is no possibility for reuse or recycle, the waste should be disposed of responsibly.

This study uses the definition of Gao et al. (2001) for recycled building materials. Gao et al. (2001) characterised as recycled building materials a material, which can be remade and reused as a building material after the building disassembled. 
Recovery or reused materials are materials that did not pass through any chemical transformation. Those materials conserved their internal structure and its physical state. However, they do not need to serve the same function as in the previous life cycle. The advantage of the reuse process is the need of less energy to make the material components suitable for its new features.

Considering the definition of both processes and the needs of French engagement to reduce the waste production to attend the European Directive, it is correct to say that reuse should have priority inside a circular economy concept. When reuse is not possible as a valorisation possibility, recycling is employed, then incineration and finally landfill, where none of the energy contained in the materials and components is used (Vefago et al., 2013).

Regarding the information about the C\&DW French generation of 2010 , it is possible to affirm that inert waste constitutes $94 \%$ of the C\&DW generation as shown in Table 1 . This inert waste has a high potential for reuse and recycles because in general, it does not require decontamination process and no significant costs are required. Much of inert waste can be reused directly on the site or another operation, and this waste can then be processed for reuse in road works (ADEME, 2012).

Table 1 C\&DW management for the French construction sector

\begin{tabular}{ll}
\hline Waste type & Production in million tons \\
\hline $\begin{array}{l}\text { Inert (soil, rocks, concrete, road demolition } \\
\text { materials, glass, construction materials) }\end{array}$ & 243.4 \\
$\begin{array}{l}\text { Non-hazardous (common industrial waste, } \\
\text { wood, drywall, metals, plastics) }\end{array}$ & 14.3 \\
$\begin{array}{l}\text { Hazardous (aerosols, oil, asbestos, paint, } \\
\text { polluted soil, tar and related products, } \\
\text { hydrocarbons and other related products, } \\
\text { batteries, accumulator, treated wood and any } \\
\text { product generated by treating wood, } \\
\text { packaging tainted by hazardous products) }\end{array}$ & 2.6 \\
\hline
\end{tabular}

Source: SOeS (2013) 
In France, when not valorised, the same inert waste, is sent to storage centres which cost from 1 to 8 Euros/ton (FFB, 2014). For instance, $44 \%$ of the C\&DW inert (333.3 million tons) was sent to the storage centres in 2004, representing an approximate annual cost (considering the cost to send to the storage centres as 4 Euros/ton) of 1.34 billion Euros for the government (IPHEN, 2007). This value could be reduced from $40 \%$ to $50 \%$ with a proper C\&DW management implementation. Moreover, non-hazardous waste that includes materials as plastic, metal, wood, and drywall, represent almost $6 \%$ of the C\&DW French generation and have a significant valorisation potential.

The available evaluation systems about the material flow measure the level of recycling economy and material flow of non-hazardous materials as metal (UNEP, 2011; Wallsten et al., 2013) or plastic based on indicators system.

With the application of sustainable development theory, it is possible to identify significant opportunities to use a circular flow approach in the waste management in France, and specifically, in the Ile-de-France (District of the Paris Region). On the one hand, $10 \%$ of gypsum, and $4 \%$ of PVC have been recycled. However, the glazing of 1.5 million windows and 4 million of square meters of carpet tiles each year (IUA îdf, 2014) that are a potential inert waste, have not been recycled but should be valorised.

All this information, aligned with the significant amount of the French C\&DW generation and the legal framework represent together a favourable scenario for the construction material's circular flow.

Under the circular economy model, resources are used with higher efficiency. The possibilities for reuse and recycling are considered crucial for minimising the pollution and the anthropogenic waste (Chen and Graedel, 2012; McDonough and Braungart, 2008; Ellen MacArthur Foundation, 2013). 


\subsection{Introduction to the waste input-output (WIO) approach}

There are many assessment methods based on specific indicators for sustainable construction practices (Horvath and Hendrickson, 1998; Fernández-Sánchez and Rodríguez-López, 2010; Mateus and Bragança, 2011; Wiedenhofer, 2015). Life cycle assessment (LCA) (Graedel, 1998; Scheuer et al., 2003), and the environmental certifications are valuable tools assisting people to identify environmental improvement opportunities to increase awareness. However, to understand the influencing factors for intensity shifts in material consumption and the mains impacts, waste input-output approach (WIO) is used.

In the current study, the main method of input-output analysis links WIO (Nakamura and Kondo, 2002, 2009) with a circular economy assessment. Input-output analysis is one of a set of related methods which shows the relation between the commodities and the industries. The WIO is a hybrid methodology of LCA which considers all phases of life- cycle, production, use, and End of Life (EoL) (Li, 2012). This method is very effective as a tool for waste management and is used in various countries such as China.

\subsection{The calculation of benefit rate of recycling economy}

The residuals of production processes called pollutants have been traditionally treated in the economics literature for the externalities theory by Pigou through the costs or benefits of activities, so-called 'spillovers' (Pigou, 1920). However, only effects of some types of waste, for example, the demolition waste, may usefully be considered as public interest. This work aims to adapt the input-output model with an emphasis on empiricism.

Input-output model based on waste accounting identities can include conveniently material flow and waste (Victor, 1972). These can be subdivided into the raw material (metal, wood, paper, plastics, concrete, rock, sand, glass, and tile) and main processes (construction, demolition, general civil and renovation). 
Table 2 Waste input-output model for the construction sector

\begin{tabular}{|c|c|c|c|c|c|c|}
\hline & Construction & Demolition & $\begin{array}{c}\text { General } \\
\text { civil }\end{array}$ & Renovation & Waste & $\begin{array}{l}\text { Output } \\
\text { waste }\end{array}$ \\
\hline Metal & $z_{i j}$ & $z_{1 j}$ & $\ldots$ & $Z_{n j}$ & $W_{j}$ & $O W_{j}$ \\
\hline Wood & $z_{i 2}$ & $z_{2 j}$ & $\ldots$ & $z_{n 2}$ & $W_{2}$ & $O W_{2}$ \\
\hline Plastic & ; & $\cdots$ & $\cdots$ & ; & ; & ; \\
\hline Paper & ; & $\cdots$ & $\cdots$ & : & : & : \\
\hline Concrete & : & $\cdots$ & $\cdots$ & $\vdots$ & : & $\vdots$ \\
\hline Rock/rubble & ; & $\cdots$ & $\cdots$ & : & : & : \\
\hline Sand/soil & $\vdots$ & $\cdots$ & $\cdots$ & ! & : & : \\
\hline Glass/tile & : & $\ldots$ & $\ldots$ & : & : & : \\
\hline Others & $z_{\text {in }}$ & $\cdots$ & $\cdots$ & $z_{n n}$ & $W_{n}$ & $O W_{v}$ \\
\hline
\end{tabular}

Table 2 sets the WIO model for the construction sector where the data on construction sector is used to calculate the coefficient of cumulative waste reduction; $O W_{i j}$ means the total waste output contribution to the main production stage $j$ using raw materials $i$ (see Appendix $\mathrm{C}$ ). In other words, Table 2 establishes a circular economy framework for the construction industry.

The general purpose of constructing the WIO model and the attendant analytical tools is to better understand the flow material inside the building process. For this purpose, the waste reduction in each construction stage is studied.

This paper uses the coefficient of cumulative waste reduction (Li, 2012).

$$
a_{i}=\frac{\sum_{j=1}^{n} z_{i j}}{O W_{i}} \quad i, j=1,2, \ldots, n
$$

where $z_{i j}$ is the raw materials, $i$ which is used in the main production stage $j$ and $a_{i}$ is the waste reduction rate within the construction material (metal, wood, paper, plastics) in waste total output (see Table 3 and Appendix B).

Also, we would define a specific case of $a_{i}$. It defines the direct waste reductions $a_{i j}$ within the main production stage, so it is:

$a_{i j}=\frac{z_{i j}}{O W_{j}} \quad i, j=1,2, \ldots, n$ 
where $a_{i j}$ is the waste reduction rate within the main production stage $j$ in per unit waste production of the construction material (see Appendixes $\mathrm{C}$ and $\mathrm{D})$.

From the traditional input-output method (Leontief, 1936), this paper defines $A$ (the direct reduction coefficient matrix) and $B$ (the complete reduction coefficient matrix) knowing that $\mathrm{B}$ indicates the waste complete reduction coefficient within the construction material $i$ in the stage $j(\mathrm{Li}, 2012)$ :

$A=\left\{a_{i j}\right\}=\left[\begin{array}{cccc}a_{11} & a_{12} & \cdots & a_{13} \\ a_{21} & a_{22} & \cdots & a_{2 n} \\ \vdots & \vdots & \vdots & \vdots \\ a_{n 1} & a_{n 2} & \cdots & a_{n n}\end{array}\right] B=\left\{b_{i j}\right\}=\left[\begin{array}{cccc}b_{11} & b_{12} & \cdots & b_{13} \\ b_{21} & b_{22} & \cdots & b_{2 n} \\ \vdots & \vdots & \vdots & \vdots \\ b_{n 1} & b_{n 2} & \cdots & b_{n n}\end{array}\right]=(I-A)^{-1}-I$ (3)

where $B$ shows the amount of waste that can be directly or indirectly reduced of raw materials $i$ in the main production stage $j$. Defined $b_{j}$ as the benefit contribution rate of recycling economy. If $b_{j}$ $>1$ through the mode of the circular economy (Li, 2012).

$b_{j}=\sum_{i=1}^{n} b_{i j} \quad i=1,2, \ldots, n$

\subsection{Data collection}

The main construction materials are concrete, metal, wood, sand and the other (see Table 3). We chose these materials as the accounting for waste reduction.

For solving this waste reduction, data is mainly collected from the French Institute for the Environment (IFEN). This information is adapted using the percentage of construction waste composition published by Hong-Kong City (Shen et al., 2004) (see Table 3).

Despite the fact that recycles rate depends on the building side, construction technologies, and the other factors, we used standard recycle rate for each tape of material (Table 4) to calculate the waste reduction amount related to the circular economy issue. 
Table 3 Waste of French construction sector

\begin{tabular}{lcccc}
\hline $\begin{array}{c}\text { Material type } \\
\text { Millions of tons }\end{array}$ & Demolition & $\begin{array}{c}\text { General civil } \\
\text { work }\end{array}$ & $\begin{array}{c}\text { Construction } \\
\text { site }\end{array}$ & $\begin{array}{c}\text { Renovation } \\
\text { work }\end{array}$ \\
\hline Metal & 1.25 & 14.63 & 0.03 & 0.68 \\
Wood & 1.56 & 20.48 & 0.00 & 0.68 \\
Plastic & 0.62 & 8.78 & 0.00 & 0.68 \\
Paper & 0.62 & 5.85 & 0.00 & 0.14 \\
Concrete & 23.40 & 204.75 & 1.28 & 9.45 \\
Rock/rubble & 0.62 & 2.93 & 0.16 & 0.00 \\
Sand/soil & 1.56 & 0.00 & 1.28 & 0.00 \\
Glass/tile & 0.94 & 5.85 & 0.00 & 1.35 \\
Others & 0.62 & 29.25 & 0.16 & 0.54 \\
Total & 31.20 & 292.50 & 3.2 & 13.50 \\
\hline
\end{tabular}

Source: IPHEN (2007) and Shen et al. (2004)

Table 4 Recycle rate of French construction sector

\begin{tabular}{lc}
\hline Material type & Recycle rate \\
\hline Metal & 10 \\
Wood & 7 \\
Plastic & 2 \\
Paper & 60 \\
Concrete & 60 \\
Rock/rubble & 44 \\
Sand/soil & 44 \\
Glass/tile & 60 \\
\hline Others & 60
\end{tabular}

\section{Results and discussion}

\subsection{Case study of the construction sector and data collection}

The qualitative evaluation model that describes the waste output categories, exchange and releases in the production and the consumption during the building construction process is established based on (WIO) tools. For this analysis, we build two scenarios simulations: business as usual scenario (BAU), a scenario without recycling activities (recycle rate $=0$ ), and another with recycling activities as indicated in Table 4 (recycle rate $\neq 0$ ). In both scenarios, the method incorporated implicitly states an important distinction between the flow resources and the fund resources (Georgescu-Roegen, 1971, 1979, 1984; Mayumi, 2001; Daly and Farley, 2011). 
The BAU scenario and the recycling scenario consider that fourth main activities divide the construction process: construction, demolition, general civil work, and renovation work. The main waste types contemplated are metal, wood, plastic, paper, concrete, rock/rubble, sand/soil, glass/tile. The WIO represents the interdependence between the flow of goods and waste in the construction process.

The results of the WIO model consider three groups of construction materials, this path permitted to be a squares matrix. In fact, using this matrix, we solved the linear system (the material $\mathrm{i}$ in the processes $\mathrm{j}$ ) as the rate of recycling economy.

"The specific meaning of the amount of waste can be reduced directly or indirectly on all production sectors while per unit of waste output produced in the production sector j" ( $\mathrm{Li}, 2012)$.

In the first group (see Figure 2) the construction materials data is composed of metal and glass/tile, wood and paper, concrete, rock/rubble and sand/soil and other materials, that are all presented in Table 3. The results showed that, in general, there is a decrease in all groups of waste when comparing the BAU and recycled scenarios. The concrete waste in the construction site and renovation work halved from the scenario of BAU to the recycled scenario due to the waste management systems that have been implemented in the French construction sites to decrease the amount of concrete sent to the landfill and the costs related to this. This concrete is recycled and used in as road construction materials for example. The waste from the mix between rock/rubber and sand/soil has dropped as well due to the high reuse of this materials in the same sector to decrease raw materials use. However, analysing both graphics (BAU scenario and recycled scenario) and the concrete, rock/rubber and sand/soil groups in the demolition activity, we can say that even if the situation improved from one scenario to another, there is still some progress to do. That occurs because in the demolition processes there is a lack of waste separation due to the difficulty in isolating the inert waste from the non-inert waste. For instance, this happens in the demolition process of gypsum waste with concrete and concrete walls with the presence of second work elements such as wood and plastic (IPHEN, 2007).

Figure 2 First group of the French construction material, (a) scenario BAU, (b) scenario recycle

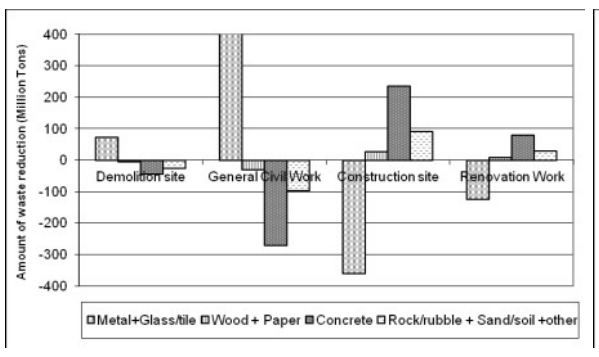

(a)

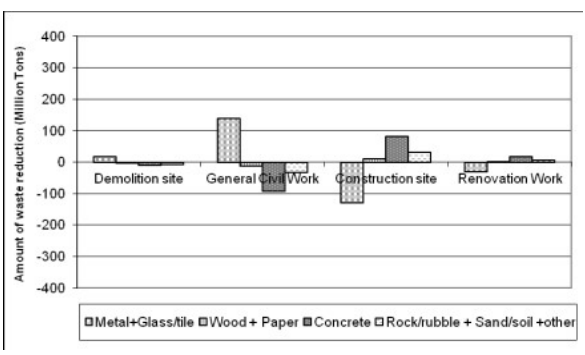

(b) 
For the second group (see Figure 3), the available construction material data is aggregated in plastic, wood, paper and metal, concrete, rock/rubble, sand/soil, glass/soil and the other material of Table 3. There is a big reduction of plastic waste in the construction site and general civil work activities when comparing the BAU and recycled scenarios.

Figure 3 Second aggregation of the French construction material, (a) scenario BAU (b) scenario recycle

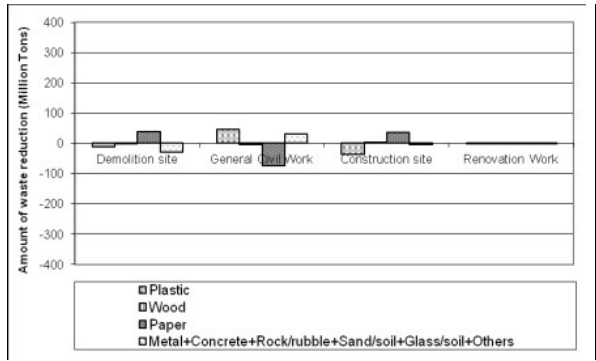

(a)

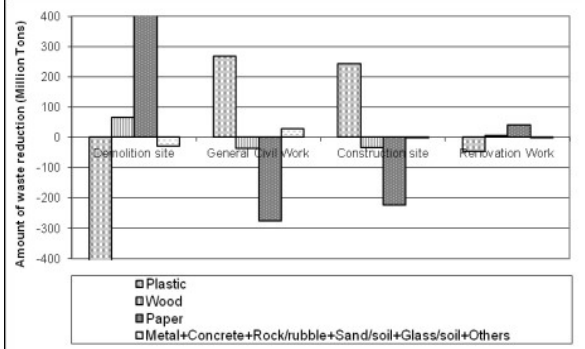

(b)

Through the material recycling process, several finished products (e.g., trash bags, pipes, profiles, cans, containers) can include plastic in their composition. However, even with big advantages in recycling plastic, in France, as showed in Table 4, there is a low recycle rate for the construction sector. Regarding this information, it is possible to affirm that the plastic in the construction industry (PVC) in France is not mainly recycled, and in general, is transformed in energy recovery. Nonetheless, plastic from the demolition site does not represent big waste reduction due to the high contamination rate by dangerous materials, what implies consequently in a low valorisation rate.

The same happened with paper and wood when comparing the BAU and the recycled scenarios inside the demolition site activities (see Figure 3). The optimisation of materials separation might help to increase the valorisation of materials like paper and wood. The recycling process of wood can result in different materials as chipboard and paper pulp, or it can be used for energy recovery in industrial boilers equipped with the flue gas treatment system. The little amount of the paper in the demolition site might be an explanation for the substantial reduction of paper at the demolition site.

For the third group (see Figure 4) construction material data for rock/rubble, sand/soil and glass/tile, metal and the other material from Table 3 are grouped. 
Figure 4 Third aggregation of the French construction material, (a) scenario BAU, (b) scenario recycle

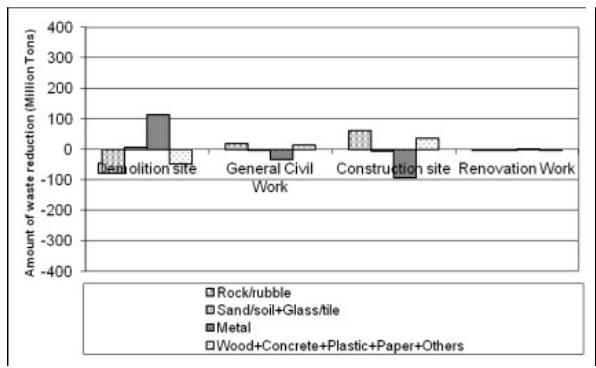

(a)

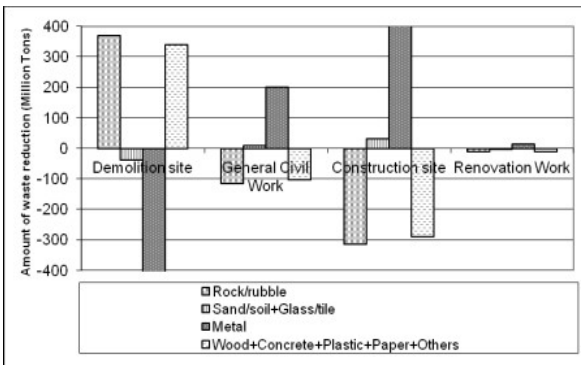

(b)

It is correct to affirm that rock/rubble and wood, concrete, plastic, and papers present a significant waste reduction through the model of circular economy comparing the BAU scenario from the recycled one.

In general, civil work in the construction site activities, when comparing both scenarios glass can be recycled, especially the windows glass, that can be used to manufacture glass bottles. Tiles can be recycled as well. Moreover, since they are free from dangerous substances (Vefago, 2013), glass and tiles can be valorised. Also, in both activities, when comparing both scenarios, it is possible to notice a significant reduction in the waste of metal. Metal can be melted and recycled and used in metallurgy and steel industry in almost all the construction activities, however, for the demolition site, the amount of waste reduction is negative due to the presence of dangerous substances that disables the valorisation process.

\section{Conclusions}

Inside the urgent scenario of EU Waste Framework Directive 2008/98/CE (Europe, 2008), and the French National Program for Waste Prevention, this study applied the input-output model to the construction sector using a combination of various approaches. In the present case, the environmentally extensive Input-Output analysis is combined with circular economy issues to evaluate the French construction situation.

This paper extended the way of assessing the relative sustainability of material flow in particular construction commodities and process from resource supply chain, resource use, and waste generation. The research can be disaggregated into the following three steps: a physical input-output table of eight commodities and fourth processes has been created, linking some physical flows with the recycling possibilities. Then the data is aggregated in square matrices of fourth commodities by fourth processes, employing the approach proposed by Li (2012) for the development of a circular economy index. 
The method permits to compare each construction material with a sustainability point of view. The application of this approach to the comparative analysis of two different scenarios showed that, in France, the building and the demolition site especially implement waste management processes. From the assessment of both scenarios, it is possible to note on the construction site a reduction of waste of concrete, metal, and plastic. However, when analysing the demolition site, results for the circular economy is negative for concrete, even with the considerable amount of this type of material waste during the demolition site, plastic, and metal. The main explanation for the negative results for concrete, plastic, and metal for the demolition site, is the lack of a properly waste separation during this process and also the presence of dangerous substances that prevent the valorisation process.

Under the circular economy concept, it is evident that waste management has much importance. Without a strategy of waste separation and proper storage in the construction or demolition site, the waste goes directly to the landfill, increasing environmental and economic impacts, because if the waste can be recycled or reused is because the waste has its value.

This paper aims to preserve the value of these constructions material through either direct re-use in another building or by 'up-cycling', retaining or even increasing their initial value. All this context could encourage the development of innovations focused on the subjects such as the concrete recycling, and also stimulate the society to realise the value of materials waste in the supply chain.

\section{References}

Acquaye, A.A. and Duffy, A.P. (2010) 'Input-output analysis of Irish construction sector greenhouse gas emissions', Building and Environment, Vol. 45, No.3, pp.784-791, DOI: 10.1016/j.buildenv.2009.08.022.

ADEME (2010) Recycle process in France, 2010 Annual report, 23 pages.

ADEME (2012) Waste Management and Valorisation in the Construction Site, 27 pages.

Blengini, G.A. (2009) 'Lifecycle of buildings, demolition and recycling potential: a case study in Turin, Italy', Building and Environment, Vol. 44, pp.313-330, DOI: 10.1016/ j.buildenv.2008.03.00.

Bourg, D. (2010) 'Réintroduire de la finitude dans le système économique', La Chair et le Souffle, Vol. 5, No. 2, pp.60-66.

Chen, W.Q. and Graedel, T.E. (2012) 'Anthropogenic cycles of the elements: a critical review', Environ. Sci. Technol., Vol. 46, No. 16, pp.8574-8586, DOI: 10.1021/es3010333.

Daly, H.E. (1968) 'On economics as a life science', Journal of Political Economics, Vol. 76, pp.392406, DOI: $10.1086 / 259412$.

Daly, H.E. and Farley, J. (2011) Ecological Economics: Principles and Applications, Island Press, 2nd ed., DOI: 10.1016/j.ecolecon.2005.08.002.

Duchin, F. (1990) 'The conversion of biological materials and wastes to useful products', Structural Change and Economic Dynamics, Vol. 1, No. 2, pp.243-261, DOI: 10.1016/0954349X(90)90004-R.

Ellen MacArthur Foundation (Ed.) (2013) 'Towards the circular economy', Economic and Business Rationale for an Accelerated Transition [online] https://www.ellenmacarthurfoundation.org/ assets/downloads/TCE_Ellen-MacArthur-Foundation_9-Dec-2015.pdf (accessed in 14 April 2016).

European Parliament (2008) 'Directive 2008/98/CE of the European Parliament and of the Council of 19 November 2008 on Waste and Certain Directives', Official Journal of the European Union. 
Eurostat (2014) Waste Generation by Economic Activity and Households in 2010 [online] http://ec.europa.eu/eurostat/statisticsexplained/index.php/File:Waste_generation_by_e conomic_activity_and_households,2010.png (accessed in 14 April 2015).

Fernández-Sánchez, G. and Rodríguez-López, F. (2010) 'A methodology to identify sustainability indicators in construction project management - application to infrastructure projects in Spain', Ecological Indicators, Vol. 10, No. 6, pp.1193-1201, DOI: 10.1016/ j.ecolind.2010.04.009.

FFB (2014) 'Construction site waste', Answers to Questions that You Might Know, Paris, France, p.20.

Gangolells, M., Casals, M., Gassó, S., Forcada, N., Roca, X. and Fuertes, A. (2009) 'A methodology for predicting the severity of environmental impact related to the construction process of residential buildings', Building and Environment, Vol. 44, No. 3, pp.558-571, DOI: 10.1016/j.buildenv.2008.05.001.

Gangolells, M., Casals, S., Forcada, N. and Macarulla, M. (2014) 'Analysis of the implementation of effective waste management practices in construction projects and sites', Resources, Conservation and Recycling, Vol. 93, pp.99-111, DOI: 10.1016/j.resconrec.2014.10.006.

Gao, W., Ariyama, T., Ojima, T. and Meier, A. (2001) 'Energy impacts of recycling disassembly materials in residential buildings', Energy and Buildings, Vol. 33, No. 6, pp.553-562, DOI: 10.1016/S0378-7788(00)00096-7.

Graedel, T.E. (1998) Streamlined Life-Cycle Assessment, Prentice Hall, New Jersey.

Horvath, A. and Hendrickson, C. (1998) 'Steel versus steel-reinforced concrete bridges: an environmental assessment', Journal of Infrastructure Systems, Vol. 4, No. 3, pp.111-117, DOI: 10.1061/(ASCE)1076-0342(1998)4:3(111).

IPHEN (2007) Recycle Process in the building and the Civil Work Sector can Progress, No. 116, pp.7-27.

Isard, W., Bassett, K., Choguill, C., Furtado, J., Izumita, R., Kissin, J., Romanoff, E., Seyfarth, R. and Tatlock, R. (1968) 'On the linkage of socio-economic and ecologic systems', papers in Regional Science, Vol. 21, pp.79-99, doi:10.1111/j.1435-5597.1968.tb01441.x.

IUA îdf. (2014) 'Circular economy, industrial ecology', Elements to reflex inside the scale of Île-de-France [online] https://www.iau-idf.fr/fileadmin/NewEtudes/Etude_1036/ Economie_circulaire_Ecologie_industrielle_IdF.pdf (accessed in 20 April 2016).

Jaillon, L., Poon, C.S. and Chiang, Y.H. (2009) 'Quantifying the waste reduction potential of using prefabricated in building construction in Hong Kong', Waste Management, Vol. 1, No. 29, pp.309-320, DOI: 10.1016/j.wasman.2008.02.015.

Jiménez, J.R., Ayuso, A.P., Galvin, M., López, M. and Agrela, F. (2012) 'Use of mixed recycled aggregates with a low embodied energy from non-selected CDW in unpaved rural roads', Construction and Building Materials, Vol. 34, pp.34-43, DOI: 10.1016/ j.conbuildmat.2012.02.042

Leontief, W. (1936) 'Quantitative input and output relations in the economic system of the United States', Review of Economics and Statistics, Vol. 18, pp.105-125, DOI: 10.2307/1927837.

Li, S. (2012) 'The research on quantitative evaluation of circular economy based on waste inputoutput analysis', Procedia Environmental Sciences, Vol. 12, pp.65-71, DOI: 10.1016/ j.proenv.2012.01.248.

Lu, W. and Tam, V.W.Y. (2013) 'Construction waste management policies and their effectiveness in Hong Kong: a longitudinal review', Renewable and Sustainable Energy Reviews, No. 23, pp.214-223, DOI: 10.1016/j.rser.2013.03.007.

Mateus, R. and Bragança, L. (2011) 'Sustainability assessment and rating of buildings: developing the methodology SBToolPTeH', Vol. 46, No. 10, pp.1962-1971, DOI: http://dx.doi.org/ 10.1016/j.buildenv.2011.04.023.

Mayumi, K. (2001) The Origins of Ecological Economics: The Bioeconomics of GeorgescuRoegen, Routledge, London, UK.

McDonough, W. and Braungart, M. (2008) Cradle to Cradle: Remaking the Way We Make Things, 1st ed., 22 April 2002, North Point Press.

Nakamura, S. and Kondo, Y. (2002) 'Input-output analysis of waste management', Journal of Industrial Ecology, Vol. 6, No. 1, pp.39-64, DOI: 10.1016 /j.buildenv.2011.04.023.

Nakamura, S. and Kondo, Y. (2009) 'Waste input-output: concepts and application to industrial ecology', Eco-efficiency in Industrial and Science, p.26. 
Nässén, J., Holmberg, J., Wadeskog, A. and Nyman, M. (2007) 'Direct and indirect energy use and carbon emissions in the production phase of buildings: an input-output analysis', Energy, Vol. 32, No. 9, pp.1593-1602, DOI: 10.1016/j.energy.2007.01.002.

O'Connor, M. (1989) 'Codependency and indeterminacy: a critique of the theory of production', Capitalism Nature Socialism, Vol. 1, No. 3, pp.33-57, DOI: http://dx.doi.org/10.1080/ 10455758909358383.

OECD (2008) OECD Environmental Outlook to 2030, OECD Rights and Translation unit (PAC), Paris, France, p.14.

Ortiz, O., Pasqualino, J.C. and Castells, F. (2010) 'Environmental performance of construction waste: comparing three scenarios from a case study in Catalonia, Spain', Waste Management, Vol. 30, pp.646-654, DOI: 10.1016/j.wasman.2009.11.013.

Passet, R. (1979). L'économie et le vivant (The Economy and Living), Payot, Paris.

Pigou, A.C. (1920) The Economics of Welfare, 1st ed., Macmillan, London.

Rodríguez, G., Alegre, F.G. and Martínez, G. (2011) 'Evaluation of environmental management resources (ISO 14001) at civil engineering construction worksites: a case study of the community of Madrid', Journal of Environmental Management, Vol. 92, No. 2, pp.1858-1866, DOI: 0.1016/j.jenvman.2011.03.008.

Saez, P.V., Merino, R.M. and San-Antonio González, A. (2013) 'Best practice measures assessment for construction and demolition waste management in building constructions', Resources, Conservation and Recycling, Vol. 75, pp.52-62, DOI: 10.1016/ j.resconrec.2013.03.009.

Scheuer, C., Keoleian, A.G. and Reppe, P. (2003) 'Life cycle energy and environmental performance of a new university building: modeling challenges and design implications', Energy and Buildings, Vol. 35, No. 10, pp.1049-1064, DOI: 10.1016/S0378-7788(03)00066- 5.

Shen, L.Y., Vivian, W.Y.T., Tam, C.M. and Drew, D. (2004) 'Mapping approach for examining waste management on construction sites', Journal of Construction Engineering and Management, pp.472-481, DOI: 10.1061/asce0733-93642004130:4472.

SOeS (2013) French Service of Observation and Statistics, Numbers and statistics, No. 385.

Stern, N., Peters, S., Bakhshi, V., Bowen, A., Cameron, C. et al. (2006) 'Stern review: the economics of climate change', London HM Treasury, p.679, DOI: 10.1111/j.1728- 4457.2006.00153.x.

UN (2012) World Population Prospects, the 2012 Revision - 'Low variant' and 'High variant' values." Retrieved April 14, 2015.

UNEP (2011) Recycling Rates of Metals - A Status Report.

US EPA (2016) Green Buildings [online] https://archive.epa.gov/greenbuilding/web/html/ (accessed 10 October 2016).

Vefago, L.H.M. and Avellaneda, J. (2013) 'Recycling concepts and the index of recyclability for building materials', Resources, Conservation and Recycling, Vol. 72, pp.127-135, DOI: 10.1016/j.resconrec.2012.12.015.

Victor, P. (1972) Pollution: Economy and Environment, Toronto University Press, Toronto.

Wallsten, B., Carlsson, A., Frändegård, P., Krook, J. and Svanström, S. (2013) ‘To prospect an urban mine - assessing the metal recovery potential of infrastructure 'cold spots' in Norrköping, Sweden', Journal of Cleaner Production, Vol. 55, pp.103-111, DOI: 10.1016/ j.jclepro.2012.05.041.

Wiedenhofer, D., Steinberger, J.K., Eisenmenger, N. and Haas, W. (2015) 'Maintenance and expansion: modeling material stocks and flows for residential buildings and transportation networks in the EU25', Journal of Industrial Ecology, Vol. 19, pp.538-551, DOI: $10.1111 /$ jiec. 12216 . 


\section{Appendix A}

Table A1 Waste generation by economic activity and households in EU in 2010 (see online version for colours)

\begin{tabular}{|c|c|c|c|c|c|c|c|}
\hline & 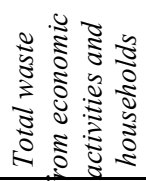 & 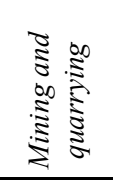 & 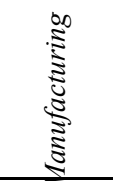 & $\begin{array}{c}\text { केते } \\
\text { ईँ } \\
\text { 这 }\end{array}$ & 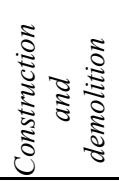 & 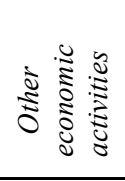 & 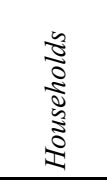 \\
\hline EU-28 & $2,505,660$ & 671,830 & 275,960 & 86,040 & 859,870 & 392,360 & 219,600 \\
\hline Belgium & 62,537 & 1,701 & 14,543 & 1,210 & 18,165 & 22,239 & 4,679 \\
\hline Bulgaria & 167,396 & 150,214 & 3,306 & 8,032 & 79 & 2,235 & 3,529 \\
\hline Czech Republic & 23,758 & 115 & 4,202 & 1,540 & 9,354 & 5,212 & 3,334 \\
\hline Denmark & 20,965 & 41 & 1,919 & 517 & 3,176 & 12,877 & 2,436 \\
\hline Germany & 363,545 & 24,493 & 48,981 & 9,087 & 190,990 & 53,682 & 36,312 \\
\hline Estonia & 19,000 & 6,453 & 3,716 & 6,534 & 436 & 1,430 & 430 \\
\hline Ireland & 19,808 & 2,196 & 3,259 & 334 & 1,610 & 10,679 & 1,730 \\
\hline Greece & 70,433 & 44,793 & 4,941 & 11,029 & 2,086 & 2,387 & 5,198 \\
\hline Spain & 137,519 & 31,732 & 16,480 & 2,339 & 37,947 & 25,823 & 23,198 \\
\hline France & 355,081 & 1,053 & 20,382 & 993 & 260,226 & 43,121 & 29,307 \\
\hline Croatia & 3,158 & 29 & 634 & 108 & 8 & 2,379 & 0 \\
\hline Italy & 158,628 & 706 & 35,928 & 2,660 & 59,340 & 27,515 & 32,479 \\
\hline Cyprus & 2,373 & 382 & 132 & 3 & 1,068 & 327 & 461 \\
\hline Latvia & 1,498 & 1 & 375 & 25 & 22 & 382 & 694 \\
\hline Lithuania & 5,583 & 7 & 2,653 & 68 & 357 & 1,238 & 1,261 \\
\hline Luxembourg & 10,441 & 18 & 867 & 2 & 8,857 & 437 & 250 \\
\hline Hungary & 15,735 & 87 & 3,134 & 2,718 & 3,072 & 3,859 & 2,865 \\
\hline Malta & 1,353 & 57 & 9 & 0 & 988 & 150 & 150 \\
\hline Netherlands & 119,255 & 184 & 14,094 & 1,156 & 78,064 & 16,685 & 9,072 \\
\hline Austria & 34,883 & 269 & 2,958 & 453 & 9,010 & 17,569 & 4,623 \\
\hline Poland & 159,458 & 61,547 & 28,618 & 20,291 & 20,818 & 19,294 & 8,890 \\
\hline Portugal & 38,347 & 1,206 & 9,766 & 456 & 11,071 & 10,386 & 5,464 \\
\hline Romania & 219,310 & 177,404 & 7,862 & 5,888 & 238 & 21,791 & 6,127 \\
\hline Slovenia & 5,159 & 12 & 1,517 & 558 & 1,509 & 835 & 728 \\
\hline Slovakia & 9,384 & 166 & 2,669 & 878 & 1,786 & 2,167 & 1,719 \\
\hline Finland & 104,337 & 54,851 & 15,211 & 1,445 & 24,645 & 6,504 & 1,681 \\
\hline Sweden & 117,645 & 89,026 & 7,823 & 1,479 & 9,381 & 5,898 & 4,038 \\
\hline UK & 259,068 & 23,092 & 19,970 & 6,239 & 105,560 & 75,258 & 28,949 \\
\hline Liechtenstein & 312 & 12 & 32 & 0 & 0 & 258 & 0 \\
\hline Norway & 9,433 & 366 & 2,687 & 28 & 1,543 & 2,580 & 2,229 \\
\hline FYR of Macedonia & 2,328 & 855 & 1,017 & 4 & 0 & 0 & 451 \\
\hline Serbia & 33,623 & 26,458 & 1,146 & 6,019 & 0 & 0 & 0 \\
\hline Turkey & 783,423 & 723,791 & 11,406 & 18,578 & 0 & 60 & 29,587 \\
\hline
\end{tabular}

Source: Eurostat (env/wasgen) 


\begin{tabular}{|c|c|c|c|c|c|c|c|c|}
\hline \multirow{2}{*}{$\begin{array}{l}\text { nstruction } \\
\text { material }\end{array}$} & \multicolumn{4}{|c|}{ Waste (zij) } & \multicolumn{4}{|c|}{ Recycle } \\
\hline & Demolition site & $\begin{array}{c}\text { General civil } \\
\text { work }\end{array}$ & Construction site & renovation work & Demolition site & $\begin{array}{c}\text { General } \\
\text { civil work }\end{array}$ & Constructionsite & Renovation work \\
\hline Metal & 1,25 & 14,63 & 0,03 & 0,68 & 0,1248 & 1,4625 & 0,0032 & 0,0675 \\
\hline Wood & 1,56 & 20,48 & 0,00 & 0,68 & 0,1092 & 1,43325 & 0 & 0,0473 \\
\hline Plastic & 0,62 & 8,78 & 0,00 & 0,68 & 0,01248 & 0,1755 & 0 & 0,0135 \\
\hline Paper & 0,62 & 5,85 & 0,00 & 0,14 & 0,3744 & 3,51 & 0 & 0,081 \\
\hline Concrete & 23,40 & 204,75 & 1,28 & 9,45 & 14,04 & 122,85 & 0,768 & 5,67 \\
\hline Rock/rubble & 0,62 & 2,93 & 0,16 & 0,00 & 0,27456 & 1,287 & 0,0704 & 0 \\
\hline Sand/soil & 1,56 & 0,00 & 1,28 & 0,00 & 0,6864 & 0 & 0,5632 & 0 \\
\hline Glass/tile & 0,94 & 5,85 & 0,00 & 1,35 & 0,5616 & 3,51 & 0 & 0,81 \\
\hline Others & 0,62 & 29,25 & 0,16 & 0,54 & 0,3744 & 17,55 & 0,096 & 0,324 \\
\hline
\end{tabular}





\section{Appendix C}

Table C1 Waste output contribution

\begin{tabular}{|c|c|c|c|c|c|}
\hline \multirow{2}{*}{$\begin{array}{l}\text { Construction } \\
\text { material }\end{array}$} & \multicolumn{4}{|c|}{ Waste output contribution (OWij) } & \multirow[b]{2}{*}{$\Sigma O w j$} \\
\hline & $\begin{array}{l}\text { Demolition } \\
\text { site }\end{array}$ & $\begin{array}{c}\text { General } \\
\text { civil work }\end{array}$ & $\begin{array}{c}\text { Construction } \\
\text { site }\end{array}$ & $\begin{array}{c}\text { Renovation } \\
\text { work }\end{array}$ & \\
\hline Metal & 1.1232 & 13.1625 & 0.0288 & 0.6075 & 14.922 \\
\hline Wood & 1.4508 & 19.04175 & 0 & 0.62775 & 21.1203 \\
\hline Plastic & 0.61152 & 8.5995 & 0 & 0.6615 & 9.87252 \\
\hline Paper & 0.2496 & 2.34 & 0 & 0.054 & 2.6436 \\
\hline Concrete & 9.36 & 81.9 & 0.512 & 3.78 & 95.552 \\
\hline Rock/rubble & 0.34944 & 1.638 & 0.0896 & 0 & 2.07704 \\
\hline Sand/soil & 0.8736 & 0 & 0.7168 & 0 & 1.5904 \\
\hline Glass/tile & 0.3744 & 2.34 & 0 & 0.54 & 3.2544 \\
\hline Others & 0.2496 & 11.7 & 0.064 & 0.216 & 12.2296 \\
\hline$\Sigma$ Owi & 14.64216 & 140.72175 & 1.4112 & 6.48675 & \\
\hline
\end{tabular}

\section{Appendix D}

Table D1 Waste reduction rate

\begin{tabular}{lcccc}
\hline \multirow{2}{*}{$\begin{array}{l}\text { Construction } \\
\text { material }\end{array}$} & $\begin{array}{c}\text { Demolition } \\
\text { site }\end{array}$ & $\begin{array}{c}\text { General } \\
\text { civil work }\end{array}$ & $\begin{array}{c}\text { Construction } \\
\text { site }\end{array}$ & $\begin{array}{c}\text { Renovation } \\
\text { work }\end{array}$ \\
\cline { 2 - 5 } Metal & 0.083634901 & 0.9800965 & 0.00214448 & 0.04523522 \\
Wood & 0.073862587 & 0.96944646 & 0 & 0.03195977 \\
Plastic & 0.063205747 & 0.88883082 & 0 & 0.0683716 \\
Paper & 0.236041761 & 2.21289151 & 0 & 0.05106673 \\
Concrete & 0.244892833 & 2.14281229 & 0.01339585 & 0.09889903 \\
Rock/rubble & 0.300427531 & 1.40825405 & 0.0770327 & 0 \\
Sand/soil & 0.980885312 & 0 & 0.80482897 & 0 \\
Glass/tile & 0.287610619 & 1.79756637 & 0 & 0.41482301 \\
Others & 0.051023746 & 2.39173808 & 0.01308301 & 0.04415516 \\
\hline
\end{tabular}

